\begin{tabular}{|l|l|l||}
\hline \multicolumn{2}{|c|}{ PublisherInfo } \\
\hline \hline PublisherName & $:$ & BioMed Central \\
\hline \hline PublisherLocation & $:$ & London \\
\hline \hline PublisherImprintName & $:$ & BioMed Central \\
\hline \hline
\end{tabular}

\title{
An anti-oncogenic role for decorin
}

\begin{tabular}{||l|l|l||}
\hline \multicolumn{2}{|c||}{ ArticleInfo } \\
\hline \hline ArticleID & $:$ & 3757 \\
\hline \hline ArticleDOI & $:$ & $10.1186 /$ bcr-2000-66720 \\
\hline \hline ArticleCitationID & $:$ & 66720 \\
\hline \hline ArticleSequenceNumber & $:$ & 29 \\
\hline \hline ArticleCategory & $:$ & Paper Report \\
\hline \hline ArticleFirstPage & $:$ & 1 \\
\hline \hline ArticleLastPage & $:$ & 4 \\
\hline \hline & & RegistrationDate : 2000-11-30 \\
ArticleHistory & $:$ & OnlineDate $\quad 2000-11-30$ \\
\hline \hline ArticleCopyright & $:$ & Current Science Ltd2000 \\
\hline \hline ArticleGrants & $:$ & \\
\hline \hline ArticleContext & $:$ & 1305833 \\
\hline \hline
\end{tabular}


Aff1 Lawrence Berkeley National Laboratory, CA, USA

\section{Keywords}

Anti-oncogenic, breast carcinoma cell line, decorin, EGFR, ErbB2, ErbB4, tyrosine phosphorylation

\section{Introduction}

Decorin, a luecine-rich proteoglycan, is normally produced by cells in the breast tissue stroma where it is thought to play a role in matrix assembly, growth factor binding and receptor tyrosine kinase activity. Its expression pattern is consistent with a role in antagonizing cell growth and thus curbing tumor-associated behaviors. Previous studies demonstrated that one mechanism by which decorin exerts its growth-suppressive effects is via interaction with the ErbB family receptor tyrosine kinase, EGFR. However, because decorin expression also appears to influence cells that lack EGFR (eg the breast carcinoma cell line MDA-MB-453) it seemed likely that decorin might exhibit similar effects by acting cooperatively with other related ErbB family members.

\section{Aims}

To study the effects of decorin overexpression in MDA-MB-453 with regard to growth control and tumorigenic behavior and to determine the extent to which decorin-dependent behavioral responses in these cells involve other ErbB receptor tyrosine kinases.

\section{Comments}

At its most basic level, this paper explores how interactions between the stromal and the epithelial compartments play a pivotal role in controlling overall cellular homeostasis in the mammary gland. Here, we are presented with a role for the stromal proteoglycan, decorin, in suppressing tumorigenic behaviors in a breast carcinoma cell model and with data demonstrating that cytostatic effects of decorin are due at least in part to modulation of ErbB receptor tyrosine kinases. The fact that decorin affects cellular behavior through ErbB receptor tyrosine kinases is not a new finding since a similar report describing the interplay between decorin and epidermal growth factor receptor (EGFR) in A431 cells 
has been previously published (see Additional information). The novelty here is the demonstration that this decorin-dependent mechanism may antagonize breast tumor progression and that it may be utilized by more than one ErbB family member.

Given the somewhat artificial nature of expressing decorin in the context of the epithelial-derived tumor cells, it will be interesting to evaluate further the anti-oncogenic effects of decorin in relevant models in which decorin is supplied to tumor cells directly from the stromal compartment.

\section{Methods}

MDA-MB-453 cells were stably transfected with constructs containing a full-length human decorin cDNA. Three clones expressing the decorin transgene were amplified and utilized to examine the functional significance of decorin overexpression. Northern and western blot analyses were performed to evaluate the expression levels of particular genes (ie decorin, p21, ErbB receptors and phosphotyrosine levels). Cell behaviors were measured using cell growth assays, soft agar assays, and assays of differentiation in culture. Decorin binding assays were performed using a radiolabeled recombinant decorin protein. NIH3T3 cell lines expressing the four ErbB receptors independently were used to determine which receptor(s) is initially activated in response to decorin ligation.

\section{Results}

In comparison to their control counterparts, the three decorin-overexpressing MDA-MB-453 clones examined exhibited of a number characteristics and behaviors that indicate an anti-oncogenic role for decorin: an increased expression of the cdk inhibitor p21, a decreased growth potential, appearance of a more differentiated phenotype in culture, a decrease in anchorage independence for growth and a loss of tumor formation in immunocompromized mice. The levels and phosphorylation status of ErbB receptors in these cells indicated that while absolute levels of ErbB2 are significantly downregulated, ErbB2, 3 and 4 all exhibit dramatic reductions in tyrosine phosphorylation levels. Co-culture experiments indicate that decorin produced in transby genetically engineered MDA-MB-453 cells, inhibits cell growth and also attenuates ErbB2 levels and activity in control cells. Receptor binding assays demonstrated a saturable binding activity for decorin in naive MDA-MB-453 cells; with a $\mathrm{Kd}$ of $71 \mathrm{nM}$, the affinity of the observed interactions is comparable to that obtained for EGFR-expressing tumor cells. These studies show that decorin activates EGFR and ErbB4, but not Erb2 or 3. Thus, by process of elimination, decorin seems likely to attenuate ErbB2 function via heterodimerization with ErbB4 in the context of MDA-MB-453 cells.

\section{Discussion}


This study extends the authors' earlier findings of downmodulation and inactivation of EGFR by showing that stable expression of decorin also results in the attenuation of signaling through the EGFRrelated receptor tyrosine kinase, ErbB2. These studies contribute to our understanding of how growth factor receptors can be alternately regulated by unconventional, non-growth-factor ligands. Moreover, because decorin expression suppresses the tumorigenic behaviors and characteristics in both cell models studied to date, an alternate paradigm for regulating tumor progression in vivois beginning to emerge: in naturally occurring neoplasias, decorin produced by cells in the surrounding stroma may serve as a first order defense by antagonizing inappropriate cell growth of the cellular carcinoma. As such, decorin and the pathways regulating its production may be useful targets for the design of novel therapies in malignancies of the breast and other tissues.

\section{Additional information}

Csordas G, Santra M, Reed CC, Eichstetter I, McQuillan DJ, Gross D, Nugent MA, Hajnoczky G, Iozzo RV: Sustained downregulation of the epidermal growth factor receptor by decorin. A mechanism for controlling tumor growth in vivo.J Biol Chem 2000, 275:32879-32887 (PubMed abstract).

\section{References}

1. Santra M, Eichstetter I, Iozzo RV: An anti-oncogeneic role for decorin: downregulation of ErbB2leads to growth suppression and cytodifferentiation of mammary carcinoma cells. J Biol Chem. 2000, 275: 35153-35161. 